\title{
White plague-like coral disease in remote reefs of the Western Caribbean
}

\author{
Juan A. Sánchez ${ }^{1}$, Santiago Herrera ${ }^{1}$, Raúl Navas-Camacho ${ }^{2}$, Alberto Rodríguez-Ramírez ${ }^{2}$, Pilar \\ Herron $^{3}$, Valeria Pizarro ${ }^{3,4}$, Alison R. Acosta ${ }^{1}$, Paula A. Castillo ${ }^{2}$, Phanor Montoya ${ }^{2}$ \\ \& Carlos Orozco ${ }^{3}$ \\ 1. Laboratorio de Biología Molecular Marina-BIOMMAR, Departamento de Ciencias Biologicas-Facultad de Ciencias, \\ Universidad de los Andes, P.O. Box 4976, Bogotá, Colombia; juansanc@uniandes.edu.co \\ 2. Instituto de Investigaciones Marinas y Costeras, INVEMAR, Punta de Betín, Zona Portuaria, Santa Marta, \\ Colombia. \\ 3. Corporacion para el desarrollo sostenible del Archipielago de San Andres y Providencia - CORALINA, San Andres \\ Isla, Colombia. \\ 4. Fundación Universidad de Bogotá Jorge Tadeo Lozano, Bogota, Colombia.
}

Received 31-VIII-2009. C Corrected 07-XI-2009. Accepted 22-XII-2009.

\begin{abstract}
The health of coral reef communities has been decreasing over the last 50 years, due the negative effects of human activities combined with other natural processes. We present documentation of a White Plague Disease (WPD) outbreak in the Serrana Bank, an isolated Western Caribbean atoll with presumably inexistent pollutant inputs from local human settlements. In addition, this study summarizes seven years of observations on diseased corals in the nearby island of San Andrés, which in contrast is one of the most populated islands of the Caribbean. There was a massive coral mortality in the atoll lagoon $\left(14^{\circ} 27^{\prime} 53.24^{\prime \prime}, 80^{\circ} 14^{\prime} 22.27^{\prime \prime}\right.$ W, and $12 \mathrm{~m}$ depth) due to WPD on May 4 of 2003. Seventeen species were found dead or largely affected by the disease. The information resulting from GPS and manta-tow transects revealed that approximately 5.8 ha of reticulate Montastraea spp. patch reefs were lethally affected by the disease in the atoll. On May 8 of the same year we observed and calculated a mean coral cover of $7.03 \%(\mathrm{SD} \pm 2.44)$, a mean diseased coral tissue cover of $5.5 \%$ $(\mathrm{SD} \pm 1.1)$ and a $13.4 \%(\mathrm{SD} \pm 8.05)$ of recently dead coral covered with a thin filamentous algae layer; approximately $73 \%$ of mortalities caused by the disease occurred before the end of the outbreak. A rough estimate of $18.9 \%$ in recent coral cover reduction can be attributed to WPD. This represents about $82 \%$ of the total coral cover decline since 1995. Semi-enclosed environments such as atoll lagoons and the reticulate patch-reefs of Montastraea spp. seem to be particularly vulnerable to this kind of coral disease, which constitute an alert to increase the monitoring of the same kind of atoll environments. The WPD has been present in the area of the nearby island of San Andrés at a low prevalence level, with sporadic increasing peaks of disease proliferation. The peaks observed during 1999 and 2004 comprised increases of $266 \%$ and $355 \%$ respectively, suggesting an alarming progression of the disease in this area. This study includes new information of the epizoolotiology of White Plague Disease and documents the permanent prevalence and progression of the WPD in the area of San Andres Island. Rev. Biol. Trop. 58 (Suppl. 1): 145-154. Epub 2010 May 01.
\end{abstract}

Key words: Coral disease, Caribbean atoll, Serrana bank, San Andrés Island, White Plague Disease, coral reefs, Montastraea.

Together with rain forests, coral reef ecosystems have the highest biodiversity on the planet (Sebens 1994). In fact, coral reefs exhibit greater animal diversity than any other marine ecosystem (Rohwer et al. 2002). The economic value of such remarkable biodiversity has been estimated to approach $\$ 375$ billion of dollars per year (Constanza et al. 1997). However, it is not only their monetary value that makes coral reefs worth preserving, they play a critical role in the overall biological processes of the ocean and the entire planet as well. The 
health of coral reef communities has been significantly decreasing over the last 50 years, due the negative effects of human activities combined with other natural processes (Harvell et al. 2004). Right now levels of coral mortality are unprecedented (Garrison et al. 2003). Many biotic and abiotic factors acting alone or together, have been identified as causes of this decrease in coral reef coverage, e.g., temperature increase, higher ultraviolet radiation, toxic chemicals input, nutrient imbalance, predation, overgrowth of algae and infectious diseases (Hughes et al. 2003). Infectious diseases are now recognized as important modifying factors in natural systems, being involved in changes of reproduction rates, growth rates, community structure, species diversity and abundance, host genetic diversity and co-evolutionary processes of reef organisms associated with coral reef communities (Loya et al. 2001, Altizer et al. 2003). To date, up to 30 different coral diseases have been monitored worldwide, but only the pathogens of five of those diseases have been identified: Black Band Disease (Richardson et al. 1998, Weir et al. 2000, Nugues et al. 2004), Aspergillosis (Geiser et al. 1998), Bacterial Bleaching (Kushmaro et al. 2001), White Pox (Patterson et al. 2002) and White Plague Disease (Richardson et al. 1998, Drenner et al. 2003). Reservoirs are known for only three coral diseases: Black Band Disease, Aspergillosis, and White Plague Disease (Richardson et al. 1998, Weir et al. 2000, Denner et al. 2003, Nugues et al. 2004).

White Plague Disease (WPD) is one of the most common, virulent and prevalent diseases that has been observed affecting coral reefs in the Caribbean basin, which is now considered a marine disease hot spot (Harvell 1999, Weil et al. 2002, Santavy et al. 2001, Borger 2003). This disease has caused heavy losses on several coral species across this region (Richardson et al. 1998), and has created concern about the survival of coral reef communities due its rapid rate of tissue destruction, high level of contagiousness and the ability to cause widespread mortalities in most Caribbean coral species (Richardson et al. 2001, Nugues et al. 2004).
WPD has become more common during the last 40 years in the Caribbean. Regions where there have been reports of the WPD include: USA (Florida) (Dustan 1977), Puerto Rico (Bruckner \& Bruckner 1997), Jamaica (Hughes 1994, Weir et al. 2000), Colombia (Weir et al. 2000, Garzon-Ferreira et al. 2001), Venezuela (Garcia et al. 2003, Croquer et al. 2003), St. JohnUS Virgin Islands (Miller et al. 2003), Little Cayman-British Overseas Territory (Manfrino et al. 2003), Barbados (Pantos et al. 2003), St. Croix-US Virgin Islands (Pantos et al. 2003), and Mexico (Ward et al. 2006).

The Serrana Bank is located in the Southwestern Caribbean and belongs to the Archipelago of San Andres, Old Providence and Santa Catalina, Colombia. Its one of the few true oceanic atolls of the Caribbean surrounded by depths of thousands of meters (Sánchez et al. 2005). It has been inferred, for its location, that Serrana Bank has suffered little impact from local human activities (e.g. contamination). This bank was declared a Biosphere Reserve by UNESCO (Seaflower Biosphere Reserve), and active research has been developed to design a network of Marine Protected Areas-MPAs (Friedlander et al. 2003, Sánchez et al. 2005). One of the particularities of these atolls is the mid-depth (12-18m) lagoonal basin, usually covered by a dense reticulate patch-reef network (Diaz et al. 1997). These reef networks are mostly dominated by massive scleractinian corals, especially Montastraea annularis and $M$. faveolata. In this note we describe an extensive and lethal WPD outbreak observed in the lagoonal patch-reef areas of Serrana Bank. We also include the results from monitoring activity of the same disease over seven years in the nearby island of San Andrés, Colombia, which in contrast is one of the most populated islands of the Caribbean.

\section{MATERIALS AND METHODS}

During a coral reef survey at Serrana Bank and two other Southwestern Caribbean atolls, in April-May 2003, three diseases were observed and documented: White Plague 
Disease (Dustan 1977, Dustan \& Halas 1987, Richardson et al. 1998), Bleaching, and Dark Spots (Gil-Agudelo \& Garzon-Ferreira 2001). These diseases were present in different habitats throughout the banks but usually with low intensity, as it has been previously observed in these areas since the 1990s (see review in Garzon-Ferreira et al. 2001). However, WPD was particularly noticeable in the lagoonal habitats of Serrana bank towards the semi-enclosed lagoonal basins from the North and East elbowlike ends (Fig. 1; see area description in Sánchez et al. 2005). The mass coral mortality due to WPD was abrupt and extensive in the lagoon, around $14^{\circ} 27^{\prime} 53.24^{\prime \prime} \mathrm{N}, 80^{\circ} 14^{\prime} 22.27^{\prime \prime} \mathrm{W}$ (May 4, 2003), 12m depth (Fig. 1). In addition, three stations were surveyed to estimate the damage to the coral colonies and coral populations in the areas surrounding the affected zone (Fig. $3)$. Due to the severity and high incidence of WPD in the affected area, we returned to the area on May 8, 2003 (four days after the first observation) to perform a more detailed estimation of the damage caused to the coral reef by the pathogen. Photographs were taken of some of the affected colonies that had been photographed during the first visit to the area (Fig. 2 E-F). Additionally, this study included White Plague Disease data from the National Coral Reef Monitoring System of Colombia (SIMAC) that has been recorded since 1998 in a series of permanent transects at different depths and two sites in the nearby island of San Andres (Fig. 1). The stations are located West of the island, where the highest diversity and coral abundance is observed (Díaz et al. 2000).

\section{RESULTS}

At Serrana bank, the diseased colonies with portions of healthy tissue had a very sharp zone of interaction, which appeared as a white band of variable width, where tissue-less coral skeleton was perfectly visible. These observations were similar to those originally describing the White Plague Disease (Dustan 1977). Previously affected areas in coral colonies presented overgrowth of filamentous algae (Fig. 2). Seventeen coral species were observed affected by the disease on May 4, 2003. Mortality was up

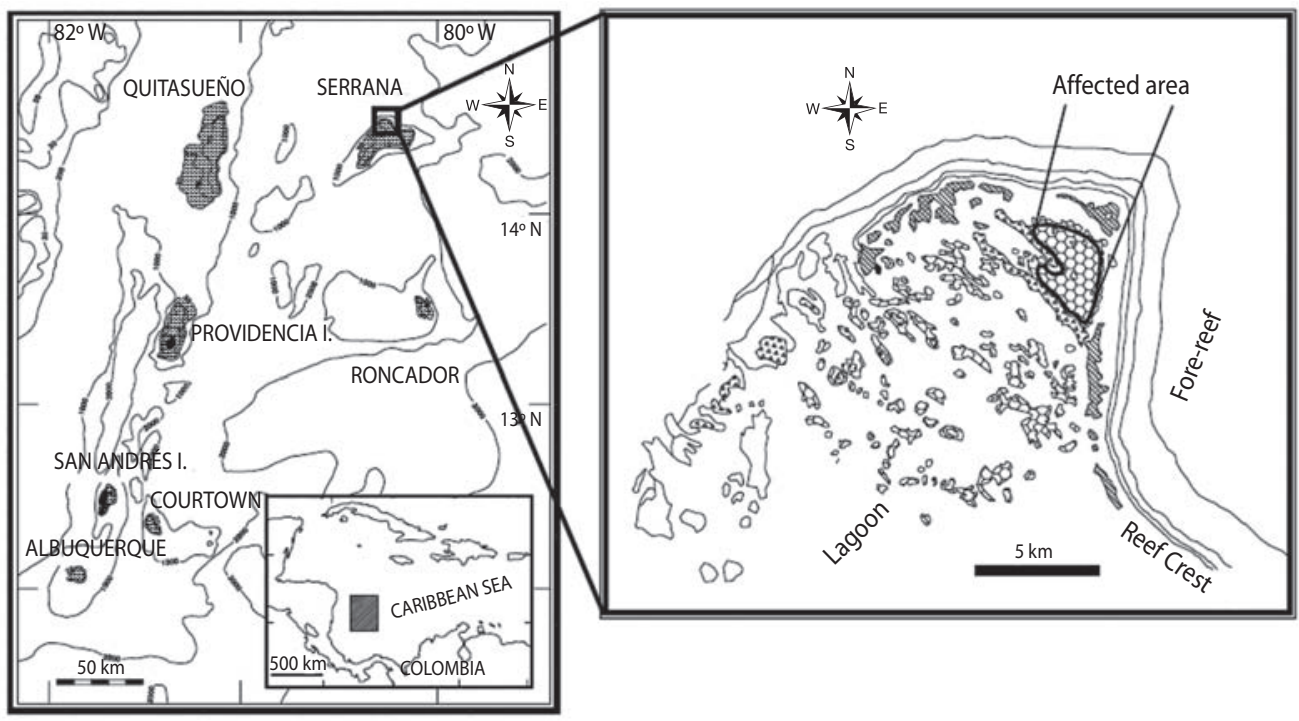

Fig. 1. Map showing the area affected by white plague-like disease in the Serrana Bank, Caribbean sea (see area details in Sánchez et al. 2005). 

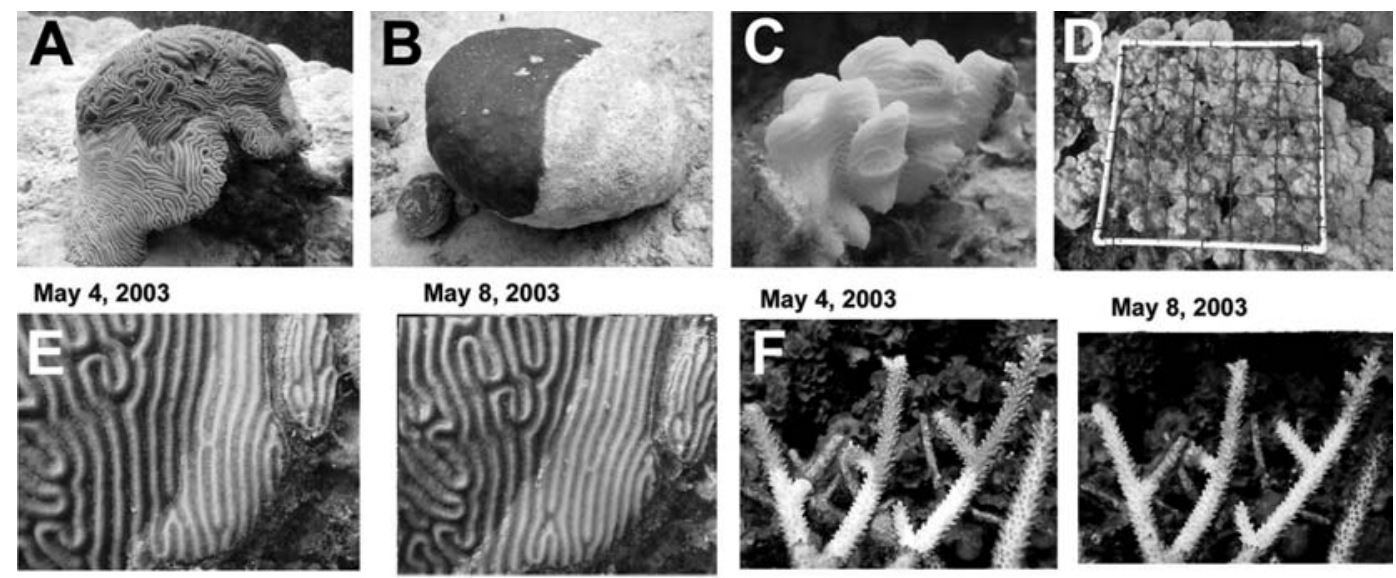

May 4, 2003

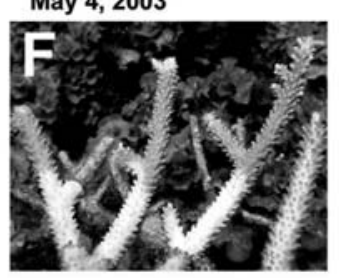

May 8, 2003
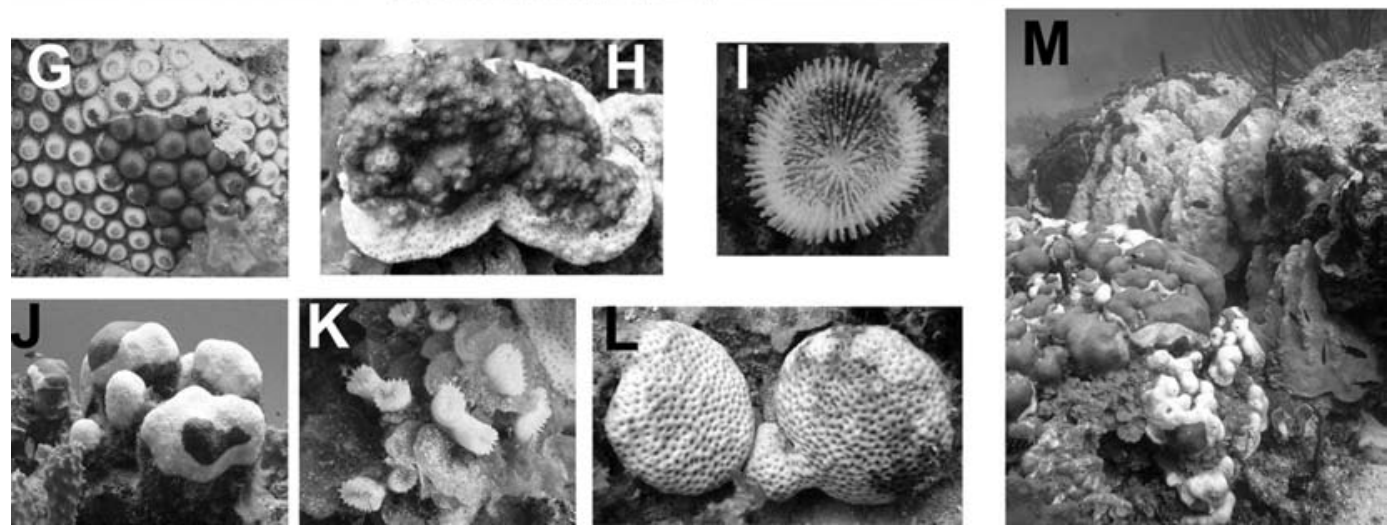

Fig. 2. Some of the species affected by a white plague-like disease in the Serrana Bank, Caribbean sea. A. Diploria labyrinthiformis, B. Stephanocoenia intersepta, C. Agaricia agaricites, D. Montastraea franksi (frame 50 x $50 \mathrm{~cm}$ ), E. Diploria strigosa, F. Acropora cervicornis, G. M. cavernosa, H. M. franksi, I. Scolymia sp., J. M. annularis, K. Eusmillia fastigiata, L. Siderastraea siderea. M. M. annularis-M. faveolata.

to $100 \%$ of recently dead coral on some of the sampled quadrants (Fig. 2). The information resulting from GPS and manta-tow transects revealed that approximately $5.8 \mathrm{ha}$ of reticulate Montastraea spp. patch reefs were uninterruptedly affected by the disease (Fig. 1). On May 8 of the same year we observed and calculated a mean coral cover of $7.03 \%(\mathrm{SD} \pm 2.44)$, a mean diseased coral tissue cover of $5.5 \%(\mathrm{SD} \pm 1.1)$ and a $13.4 \%(\mathrm{SD} \pm 8.05)$ of recently dead coral covered with a thin filamentous algae layer. This is approximately $73 \%$ of mortality caused by the disease before the end of the outbreak. A rough estimate of $18.9 \%$ in recent coral cover reduction can be attributed to WPD. Given that previously in 1995 there was $\sim 38 \%$ of total coral cover in the same area of Serrana Bank (Diaz-Pulido et al. 2004), nearly $\sim 81 \%$ of the recent coral mortality (ca. $-30 \%$ of coral cover) was caused before the end of the 2003 disease outbreak. Comparative photographs roughly revealed that the disease was growing at an approximate rate of $10 \mathrm{~mm}$ per day (Fig. 2).

The disease outbreak was observed on adjoining colonies throughout the affected reef. Nonetheless, three species were not observed infected (Mycetophyllia ferox, Leptoseris cucullata, and Millepora alcicornis) and Siderastraea siderea appeared only bleached. Porites spp. had an overall low disease incidence and 


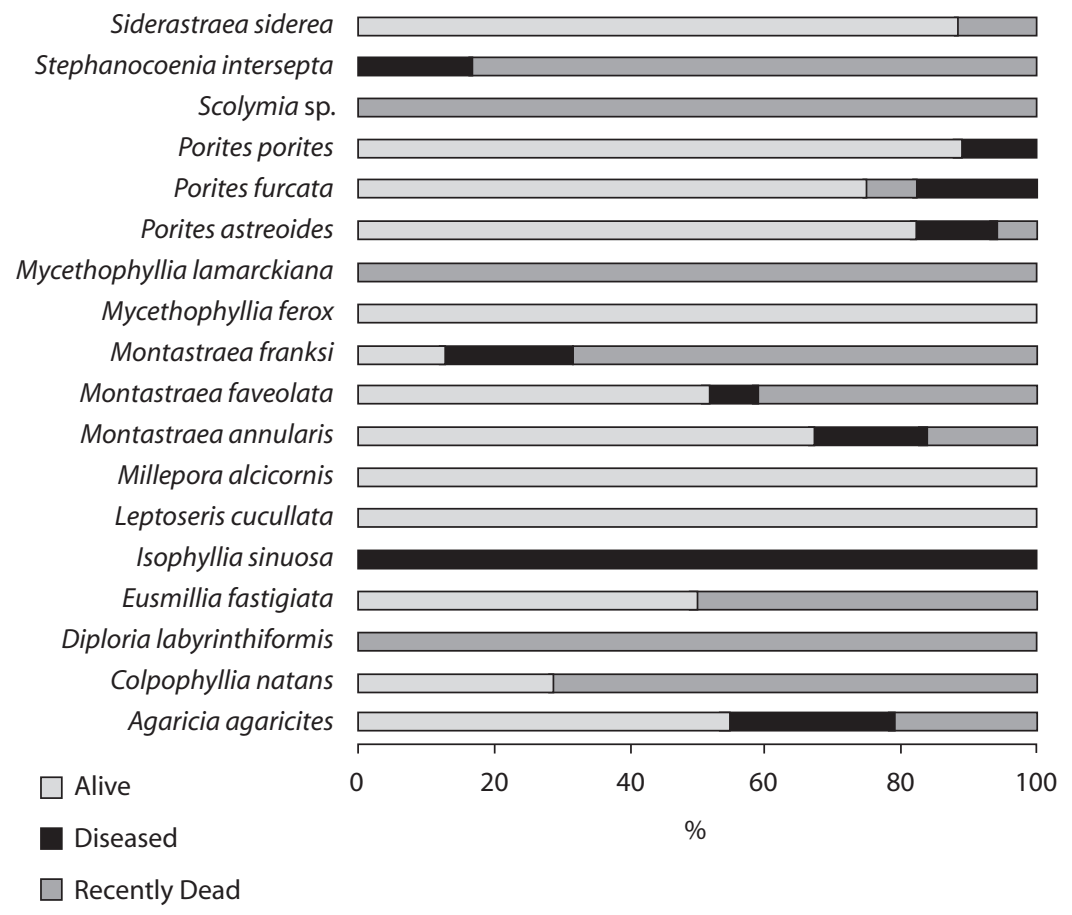

Fig. 3. Percentage per species of their relative cover respect to alive, diseased, or recently dead tissue pooled from three quantitative transects widely separated of belt-quadrants and the point intercept method (3680 points, 64 points per quadrant, see details in Sánchez et al. 2005).

mortality (Fig. 3). In contrast, most of the other species presented $>50 \%$ of their cover as recently dead (Fig. 3). The corals were observed as presumably becoming infected by the disease through contact with neighboring colonies due to the observed pattern along the patch reefs, which creates the potential of disease spread throughout the entire interconnected patch reef network. We also observed Acropora cervicornis with a white band-like disease (Fig. 2 F), this species has previously been reported as not suffering White Plague Disease (Sutherland et al. 2004). Since the disease starts at the edges of the colonies, which corresponds to the bases of branching corals, it is not possible to discern by observation between White Plague Disease and White Band in the case of A. cervicornis, particularly if these diseased colonies were in the middle of hundreds of diseased colonies with WPD.
The prevalence of WPD in the area of San Andrés ranged between a minimum value of $0.4 \%$ in 2000 and a maximum of $2.2 \%$ in 2004 (Fig. 4a), whereas the number of affected colonies ranged between 6 colonies $/ 200 \mathrm{~m}^{2}$ and 88 colonies $/ 200 \mathrm{~m}^{2}$ (Fig. 4 b). Despite that the mean annual prevalence values usually did not exceed $1 \%$ throughout the monitoring program, these observations matched the prevalence ranges for other Caribbean localities (0.0-3.2\%, Weil et al. 2002). The peaks observed during 1999 and 2004 comprised increases of $266 \%$ and $355 \%$ respectively, suggesting an alarming progression of the disease in this area. This pattern was also observed in a number of affected colonies (Fig. 4c). During the seven years of monitoring a total of 23 coral species have been observed diseased. Particularly during 2004, the worst year so far for the disease in San Andrés, 20 species were observed affected. 

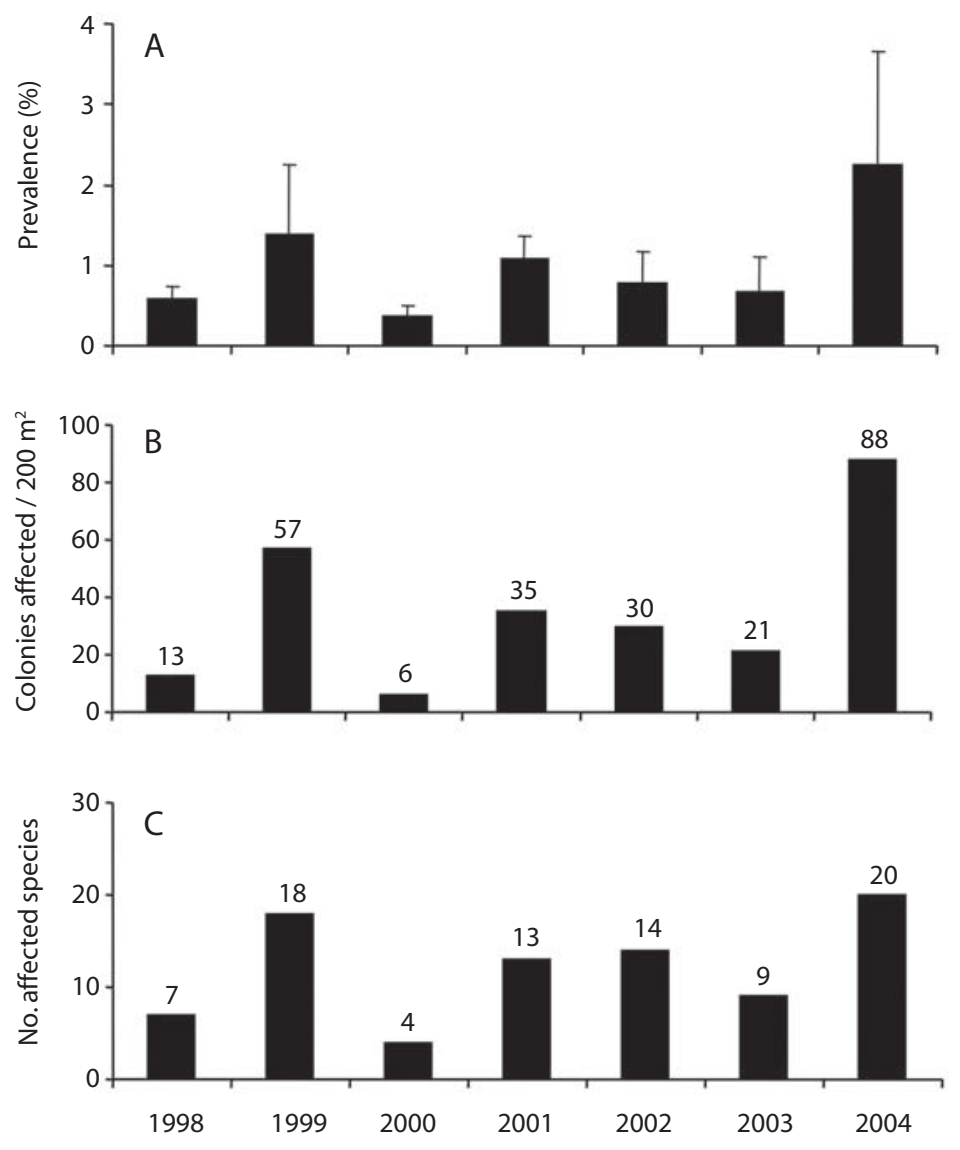

Fig. 4. A) Percentage of white plague-like disease prevalence during 1998-2004 (bars are standard errors) in San Andrés. B) Number of colonies affected $/ 200 \mathrm{~m}^{2}$. C) Number of affected species per observed year.

These include the same species observed in Serrana (Fig. 3) and also Leptoseris cucullata, Millepora alcicornis and Mycetophyllia ferox, which were not noted as diseased in Serrana.

\section{DISCUSSION}

This is the first report of a White Plague Disease (WPD) outbreak in Serrana Bank, an isolated Western Caribbean atoll, with presumably inexistent pollutant inputs from local human settlements. In addition, this study summarizes seven years of observations on diseased corals in the nearby island of San Andrés. A similar disease outbreak has been reported by Nugues (2002) in the coral reefs from St. Lucia. Unfortunately, it is impossible to determine if a given outbreak is caused by the same kind of pathogen until a standard diagnostic procedure, such as the one proposed by Richardson et al. (2005), is widely used. Despite the increasing taxonomy in plague-like diseases based on symptomatic characteristics or in single species of bacteria, the key to this type of disease seems to be the disturbance of the microbial flora of the coral tissue due to changes in environmental conditions that can 
both trigger the virulence of a pathogen and cause stress in the animal (Pantos et al. 2003).

The Serrana Bank lagoon has a semienclosed basin where water masses can reside for some period of time. This characteristic could be adverse for coral communities if the environmental conditions are different than normal (e.g., high temperature, nutrients, among others). Nonetheless, there were no high seawater surface temperature (SST) spots recorded in this area between April 29 and May 8, 2003 (University of South Florida, College of Marine Science, SST, ImaRS website). In the case of the 2003 WPD outbreak in Serrana Bank, there were two time-appealing coincidences with similar outbreaks at Corn Island (off the Nicaraguan coast: A. Hunt, pers. com.) in May, and the barrier reef off Belize (T. McClanahan, pers. com.) in July. Given the unlikeness of an eventual direct input of human locally produced pollutants in this area due its isolation from the land, it is however possible that a significant amount of nutrients and toxic compounds may have came from a remote source. It has been suggested and widely documented (Peters 1997, Goreau et al. 1998, Antonius \& Ballesteros 1998, Geiser et al. 1998, Harvell 1999) that synthetic-organic chemicals and anthropogenic pollutants, viable microorganisms, macro and micronutrients, and trace metals are likely to be carried in the wind-dust air masses and deposited in the oceans (Garrison et al. 2003). These "dusttravelers" can change the local conditions of such an enclosed lagoon environments, and therefore facilitate the sporadic and unpredictable occurrence of WPD outbreaks in human isolated reefs (Garrison et al. 2003). However, it is unknown if the three places had the same kind of disease. Consequently, more observations (both oceanographic and microbiological/ genetic) and monitoring networks along Southwestern Caribbean reefs are needed to discern the epizootiology patterns producing mass disease outbreaks such as the ones observed in Serrana Bank and other Caribbean regions.

In the island of San Andrés, these results corroborated what was found by Garzón-Ferreira et al. (2001) and Weil et al. (2002), that the area of San Andres is an important focus of White Plague Disease prevalence. However, since Serrana Bank is considerably less affected by human impact than San Andres Island, the widespread outbreak observed in Serrana suggests that the nature of these events could be due to remote wind-transported particles (e.g. dust, toxic chemicals, microorganisms) or other ocean-wide anomalies.

This study included new information of the epizoolotiology of White Plague Disease. It documented as well the permanent prevalence and progression of the WPD in the area of San Andres Island. This study should also constitute an alert to increase the monitoring of the same kind of atoll environments (e.g., lagoonal reticulate patch-reef: Diaz et al. 1997) at other coral reef provinces.

\section{ACKNOWLEDGMENTS}

This study was partially funded by The Ocean Conservancy (TOC), Washington, D.C., and CORALINA, San Andres and Providencia Archipelago, Colombia, as part of the design of a network of MPAs in the SeaFlower Biosphere reserve. Thanks to: M. Simpson, D. Heinemann (TOC), M. Prada, J. M. Mow Robinson (CORALINA), C. Dahlgren (Caribbean Marine Research Center), R. Appeldoorn (U. of Puerto Rico, Mayagüez), A., N., and N. Archibald (M/N Anglonamar 2), N. Howard, C. Rechia (TOC), J. M. Diaz (INVEMAR), M. Howard, and Cap. Ospina (CIOH-DIMAR, Colombia), L. "Lalo" Arango L., E. Arboleda, K. L. Buch, L. F. Cabeza, J. P. Caldas A., E. Castro G., R. Glazer, S. Kerr, G. Peñaloza N., O. Pinzón T., L. S. Posada, and A. Villadiego C. Comments from A. Hunt, T. McClanahan, J. Lang, L. Richardson, S. Wilson, and E. Hernandez were helpful in writing this paper. J.A. Sánchez acknowledges a Smithsonian Institution postdoctoral fellowship. The development and implementation of SIMAC in San Andrés has been possible thanks to the support of INVEMAR, CORALINA, COLCIENCIAS, UNEP-CAR/RCU, and MAVDT. 
Numerous colleagues from INVEMAR participated directly in the SIMAC's surveys: J. Garzón, M.C. Reyes, S. Bejarano, and D.L. Gil. Thanks a lot to all of them. Contribution No. CTBR-1039 from INVEMAR.

\section{RESUMEN}

Este trabajo presenta datos sobre un brote de la Enfermedad de Plaga Blanca (EPB) en el banco de Serrana y resume siete años de observaciones de esta enfermedad en la vecina isla de San Andrés (Caribe colombiano). La mortalidad masiva de corales por causa de EPB se observó en la laguna del atolón (14² $27^{\prime} 53.24^{\prime \prime}, 80^{\circ} 14^{\prime} 22.27^{\prime \prime} \mathrm{W}$, y $12 \mathrm{~m}$ de profundidad) en mayo 4 de 2003 . Se encontraron 17 especies muertas o atacadas por EPB y $5.8 \mathrm{Ha}$ de parches de Montastraea spp. fueron letalmente afectadas por la enfermedad. En mayo 8 del mismo año observamos y calculamos una cobertura promedio de coral de 7.03\% (SD \pm 2.44), un promedio de tejido coralino enfermo de $5.5 \%$ $(\mathrm{SD} \pm 1.1)$ y un $13.4 \%(\mathrm{SD} \pm 8.05)$ de coral recientemente muerto cubierto con una fina capa de algas filamentosas; aproximadamente $73 \%$ de la mortalidad a causa de la enfermedad ya había ocurrido antes de que terminara el brote de EPB. La EPB ha estado presente en el área de la vecina isla de San Andrés con un bajo nivel de prevalencia pero con esporádicos picos de proliferación de la enfermedad. Durante 1999 y 2004 se observaron incrementos de prevalencia de $266 \%$ y $355 \%$ respectivamente. Ambientes semi-cerrados como son las lagunas de los atolones y los arrecifes de parche reticulados de Montastraea spp. parecen ser especialmente vulnerables a este tipo de enfermedades coralinas, lo que constituye una alerta hacia una mayor atención y monitoreo en este tipo de ambientes lagunares en atolones.

Palabras clave: Enfermedad coralina, atolón caribeño, banco Serrana, Isla de San Andrés, enfermedad de la Plaga Blanca, arrecifes coralinos, Montastraea.

\section{REFERENCES}

Altizer, S., D. Harvell \& E. Friedle. 2003. Rapid evolutionary dynamics and disease threats to biodiversity. Trends Ecol. Evol. 18: 589-596.

Antonius, A. \& E. Ballesteros. 1998. Epizoism: A new threat to coral health in the Caribbean. Rev. Biol. Trop. 46: 145-156.

Borger, J.L. 2003. Three scleractinean coral diseases in Dominica, West Indies: Distribution, infection patterns and contribution to coral tissue mortality. Rev. Biol. Trop. 51: 25-38.
Bruckner, A.W. \& A.W. Bruckner. 1997. Outbreak of coral disease in Puerto Rico. Coral Reefs 16: 260.

Costanza, R., R. d'Arge, R. de Groot, S. Farber, M. Grasso, B. Hannon, K. Limburg, S. Naeem, R.V. O’Neill, J. Paruelo, R.G. Raskin, P. Suton \& M.van den Belt. 1997. The value of the world's ecosystem services and natural capital. Nature 387: 253-260.

Croquer, A., S.M. Pauls \& A.L. Zubillaga. 2003. White Plague Disease outbreak in a coral reef at Los Roques National Park, Venezuela. Rev. Biol. Trop. 52: 39-45.

Denner, E.M.B., G. Smith, H.J. Busse, P. Schumann, T. Narzt, S.W. Polson, W. Lubitz \& L.L. Richardson. 2003. Aurantimonas coralicida gen. nov., sp. nov., the causative agent of white plague type II on Caribbean scleractinian corals. Int. J. Syst. Evol. Microbiol. 53: 1115-1122.

Díaz, J.M., J.A. Sánchez \& J. Geister. 1997. Development of lagoonal reefs in oceanic complexes of the Southwestern Caribbean: geomorphology, structure and distribution. Proc. 8th Int. Coral Reef Symposium 1: 779-784.

Díaz, J.M., L.M Barrios, M.H. Cendales, J. GarzónFerreira, J. Geister; M. López-Victoria, G.H. Ospina, F. Parra-Velandia, J. Pinzón, B. Vargas-Angel, F.A. Zapata \& S. Zea. 2000. Áreas coralinas de Colombia. INVEMAR, Serie de Publicaciones Especiales No. 5, Santa Marta, Colombia.

Díaz-Pulido, G., J.A. Sánchez, S. Zea, J.M. Díaz \& J. Garzón-Ferreira. 2004. Esquemas de distribución espacial en la comunidad bentónica de arrecifes coralinos continentales y oceánicos del Caribe Colombiano. Rev. Acad. Colomb. Cienc. 108: 337-347.

Dustan, P. 1977. Vitality of reef coral populations off Key Largo, Florida: Recruitment and mortality. Env. Geol. 2: 51-58.

Dustan, P. \& J.C. Halas. 1987. Changes in the reef-coral community of Carysfort Reef, Key Largo, Florida: 1974-1982. Coral Reefs 6: 91-106.

Friedlander A., J. Sladek-Nowlis, J.A. Sánchez, R. Appeldoorn, P. Usseglio, C. Mccormick, S. Bejarano \& A. Mitchell-Chui. 2003. Designing effective marine protected areas in old Providence and Santa Catalina Islands, San Andrés Archipelago, Colombia, Using Biological and Sociological Information. Conservat. Biol. 17: 1769-1784.

García, A., A. Croquer \& S.M. Pauls. 2003. Estado actual de las enfermedades y otros signos de deterioro coralino en siete arrecifes del Parque Nacional 
Arichipiélago de Los Roques, Venezuela. Rev. Biol. Trop. 51: 173-180.

Garrison V.H., E.A. Shinn, W.T. Foreman, D.W. Griffin, C.W. Holmes, C.A. Kellogg, M.S. Majewski, L.L. Richardson, K.B. Ritchie \& G.W. Smith. 2003. African and Asian dust: from desert soils to coral reefs. BioScience 53: 469-480.

Garzón-Ferreira, J., D.L. Gil-Agudelo, L.M. Barrios \& S. Zea. 2001. Stony coral diseases observed in Southwestern Caribbean reefs. Hydrobiologia 460: 65-69.

Geiser, D.M., J.W. Taylor, K.B. Ritchie \& G.W. Smith. 1998 Cause of sea fan death in the West Indies. Nature 394: $137-138$.

Gil-Agudelo D.L. \& J. Garzon-Ferreira. 2001. Spatial and seasonal variation of dark spots disease in coral communities of the Santa Marta area (Colombian Caribbean). Bull. Mar. Sci. 69: 619-629.

Goreau, T. J., J. Cervino, M. Goreau, R. Hayes, M. Hayes, L. Richardson, G.W. Smith, G. DeMeyer, I. Nagelkerken, J. Garzon-Ferreira, D. Gill, E.C. Peters, G. Garrison, E.H. Williams, L. Bunkley-Williams, C. Quirolo \& K. Patterson. 1998. Rapid spread of diseases in Caribbean coral reefs. Rev. Biol. Trop. 46: 157-171.

Harvell, C.D. 1999. Emerging marine diseases-Climate links and anthropogenic factors. Science 285: $1505-$ 1510.

Harvell, C.D., R. Aronson, N. Baron, J. Connell, A. Dobson, S. Ellner, L. Gerber, K. Kim, A. Kuris, H. McCallum, K. Lafferty, B. McKay, J. Porter, M. Pascual, G. Smith, K. Sutherland \& J. Ward. 2004. The rising tide of ocean diseases: Unsolved problems and research priorities. Front. Ecol. Environ. 2: 375-382.

Hughes, T.P. 1994. Catastrophes, phase shifts, and large scale degradation of a Caribbean coral reef. Science 265: $1547-1551$

Hughes, T., A. H. Baird, D. R. Bellwood, M. Card, S. R. Connolly, C. Folke, R. Grosberg, O. Hoegh-Guldberg, J. B. C. Jackson, J. Kleypas, J. M. Lough, P. Marshall, M. Nyström, S. R. Palumbi, J. M. Pandolfi, B. Rosen \& J. Roughgarden. 2003. Climate change, human impacts and the resilience of coral reefs. Science 301: 929-933.
Kushmaro, A, E. Banin, Y. Loya, E. Stackebrandt, \& E Rosenberg. 2001. Vibrio shiloi sp. nov., the causative agent of bleaching of the coral Oculina patagonica. Int. J. Syst. Evol. Microbiol. 51: 1383-1388.

Loya, Y., K. Sakai, K. Yamazato, Y. Nakano, H. Sembali \& R. van Woesik. 2001. Coral bleaching: The winners and losers. Ecol. Lett. 4: 122-131.

Manfrino, C., B. Riegl, J.L. Hall \& R. Graifman. 2003. Status of the Coral Reefs of Little Cayman, Grand Cayman and Cayman Brac, British West Indies, in 1999 and 2000. Atoll Res. Bull. 496: 204-226.

Miller, J., C. Rogers \& R. Waara. 2003. Monitoring the coral disease, Plague Type II, on coral reefs in St. John, U.S. Virgin Islands. Rev. Biol. Trop. 51: 47-55.

Nugues, M.M. 2002. Impact of a coral disease outbreak on coral communities in St. Lucia: What and how much has been lost? Mar. Ecol. Prog. Ser. 229: 61-71.

Nugues, M.M., G.W. Smith, R. J. VanHooidonk, M.I. Seabra \& R.P.M. Bak. 2004. Algal contact as a trigger for a coral disease. Ecol. Lett. 7: 919-923.

Pantos, O., R.P.Cooney, M.D.A. Le Tissier, M.R. Barer, A.G. O'donnell \& J.C. Bythell. 2003. The bacterial ecology of a plague-like disease affecting the Caribbean coral Montastrea annularis. Env. Microbiol. 5: 370-380.

Patterson, K.L., J.W. Porter, K.B. Ritchie, S.W. Polson, E. Mueller, E.C. Peters, D.L. Santavy \& G.W.Smith. 2002. The etiology of white pox, a lethal disease of the Caribbean elkhorn coral, Acropora palmata. P. Natl. Acad. Sci. USA 99: 8725-8730.

Peters, E.C. 1997. Diseases of coral-reef organisms, p. 14-136. In C. Birkeland (eds.) Life and death of coral reefs. Chapman \& Hall, London, UK.

Richardson, L., W.M. Goldberg, K.G. Kuta, R.B. Aronson, G.W. Smith, K.B. Ritchie, J.C.Halas, J.S. Feingold \& S.M. Miller. 1998. Florida's mystery coral killer explained. Nature 392: 557-558.

Richardson L.L., G.W. Smith, K.B. Ritchie, \& R.G. Carlton. 2001. Integrating microbiological, micro-sensor, molecular, and physiologic techniques in the study of coral disease pathogenesis. Hydrobiologia 460: 71-89. 
Richardson, L.L., D.L. Mills, E.R. Remily \& J.D. Voss. 2005. Development and field application of a molecular probe for the primary pathogen of the coral disease White Plague Type II. Rev. Biol. Trop. 53: $1-10$.

Rohwer, F., V. Seguritan, F. Azam \& N. Knowlton. 2002. Diversity and distribution of coral-associated bacteria. Mar. Ecol. Prog. Ser. 243: 1-10.

Sánchez, J.A., V. Pizarro, A.R. Acosta, P.A. Castillo, P. Herron, J.C. Martínez, P. Montoya \& C. Orozco. 2005. Evaluating coral reef benthic communities from remote Caribbean atolls (Quitasueño, Serrana, and Roncador Banks, Colombia): Multivariate approaches to recommend marine protected areas for the SeaFlower Biosphere Reserve (Archipelago of San Andres and Providencia). Atoll. Res. Bull. 531: 1-65.

Santavy, D.L., E. Mueller, E.C. Peters, L. MacLaughlin, J.W. Porter, K.L. Patterson \& J. Campbell. 2001. Quantitative assessment of coral diseases in the Florida Keys: Strategy and methodology. Hydrobiología 460: 39-52.
Sebens, K. 1994. Biodiversity of coral reefs: what are we losing and why? Amer. Zool. 34: 115-133

Sutherland, K.P., J.W. Porter \& C. Torres. 2004. Disease and immunity in Caribbean and Indo-Pacific zooxanthellate corals. Mar. Ecol-Prog. Ser. 266: 273-302.

Ward, J.R., K.L. Rypien, J.F. Bruno, C.D. Harvell, E. Jordan-Dahlgren, K.M. Mullen, R.E. RodriguezMartinez, J. Sanchez \& G. Smith. 2006. Coral diversity and disease in Mexico. Dis. Aquat. Organ. 69: 23-31.

Weil, E., I. Urreiztieta \& J. Garzón-Ferreira. 2002. Geographic variability in the incidence of coral and octocoral diseases in the wider Caribbean. Proc. 9th Int. Coral Reef Symposium 2: 1231-1237.

Weir, J.R., V.H. Garrison, E.A. Shinn \& G.W. Smith. 2000. The relationship between Gorgonian coral (Cnidaria: Gorgonacea) diseases and African dust events. Abstracts 9th Int. Coral Reef Symposium, Bali, Indonesia. 